\title{
İlkokul/Ortaokul Öğretmenlerinin Doğal Afet Okuryazarlık Düzeyleri: Osmaniye İli Örneği
}

\author{
Natural DisasterLiteracyLevels of Primary/Secondary School Teachers: The Case of Osmaniye \\ Province
}

Sezai DEMIRDELEN ${ }^{1}$, Ahmet Burhan ÇAKICI ${ }^{2}$

\section{ÖZ}

$\mathrm{Bu}$ çalışmamızda afetler ile mücadele konusunda toplumun bilinç düzeyinin ve okuryazarlık düzeyinin ele alınmasını ve değerlendirilmesine önem verilmektedir. Çünkü toplumların okuryazarlık düzeyi yüksek olması, afetler ile başa çıkma ve afetin hazırlık evresinde önemli bir rol oynamaktadır. Bu çalışmanın amacı afet öncesinde hazırlık süresinde toplumun bilinç düzeylerindeki eksiklikleri ve davranış şekillerini belirlemektir. Bu çalışmamızda; Osmaniye ili merkez ilçesinde görev yapan ilkokul/ortaokul öğretmenlerinin doğal afet okuryazarlık düzeylerini belirlemek ve doğal afet okuryazarlığın alt faktörleri (davranış, duyusal eğilim ve bilgi) arasında çeşitli değişkenlerin etkisini ölçmektir. Araştırmanın verileri "Öğretmen Adaylarının Doğal Afet Okuryazarlık Düzeylerinin Belirlenmesi” isimli çalışmada geliştirilen anket formu kullanılarak toplanmıştır. Araştırmaya dâhil edilen katılımcıların doğal afet okuryazarlığ 1 davranış düzeyi puan ortalamaları (Ort=1,67, SS=0,294) doğal afet okuryazarlığı duyusal eğilim düzeyi puan ortalamaları (Ort=1,85, SS=0,255) doğal afet okuryazarlığı bilgi düzeyi puan ortalamaları (Ort=87,62, SS=9,022) olarak bulunmuştur. Araştırma sonuçlarına göre öğretmenlerin çoğunluğu doğal afetlerle ilgi faaliyetlere katıldığını ve katılmak istediğini belirtmişlerdir. $\mathrm{Bu}$ sonuç bağlamında öğretmenlere doğal afetlerle ilgili seminer, konferans, eğitim ve tatbikat gibi faaliyetler düzenlenmelidir.

Anahtar Kelimeler: Afet, Doğal Afet, Doğal Afet Okuryazarlığı.

\begin{abstract}
A little thought in our discussion with those in this study and the choice and assessment of your literacy level is valued. People's societies have a high level of literacy, coping with a success and disaster in a preparation phase in a role-playing phase. In a design design intended for this purpose, design designs shape their designs. It is the target of what is taken from those who range from the bottom of the society to disasterwriting and the lower part of natural disasterwriting (behavior, sensory perception and). The file analysis formula named "Determination of Natural Disaster Literacy Levels of Teacher Candidates" was collected from the data of the research. When we look at the people included in the study, average scores for normal literacy levels (Avg=1.67, SD=0.294), disaster literacy sensory level scores (Avg=1, $\mathrm{SD}=0.255)$, natural disaster literacy knowledge scores $(\operatorname{Avg}=1,85)$, $\mathrm{SD}=0.255)=87.62, \mathrm{SD}=9,022$ ). When considered according to the research, they stated that they are interesting and thoughtful with the disasters considered. Trainings related to these education and training activities can be organized with events such as conferences, training and exercises.
\end{abstract}

Keywords: Disaster, Natural Disaster, Natural Disaster Literacy.

\footnotetext{
*İlgili Üniversitenin Etik Kurulu’ndan 32217192-605.01-E21530583 Karar No ile etik izin ve araştırma yapılan Hastane'den kurum izni alınmıştır. Bu çalışma birinci yazarın yüksek lisans tezinden türetilmiştir.

${ }^{1}$ Öğr. Gör., Sezai DEMIRDELEN, Ardahan Üniversitesi Nihat DelibaltaGöle Meslek Yüksekokulu Mülkiyet Koruma ve Güvenlik Bölümü, sezaidemirdelen@ardahan.edu.tr, ORCID:0000-0003-4395-4560.

${ }^{2}$ Doç. Dr., Ahmet Burhan ÇAKICI, Karamanoğlu Mehmetbey Üniversitesi, İşletme Bölümü İktisadi ve İdari Bilimler Fakültesi, ahmetburhan@kmu.edu.tr, ORCID:0000-0003-4848-3278.

$\begin{array}{llr}\text { İletişim / Corresponding Author: } & \text { Sezai DEMIRDELEN } & \text { Geliş Tarihi / Received: } \\ \text { e-posta/e-mail: } & \text { sezaidemirdelen @ ardahan.edu.tr } & \text { Kabul Tarihi / Accepted: }\end{array}$




\section{GİRIS}

İnsanlığın yeryüzünde ortaya çıkışından beri toplumlar ve afetler her dönem etkileşim halinde olmuştur. Bu etkileşim çoğu zaman insanlara ciddi zarar vermiştir. Afetlerin özelliğine baktığımız zaman ise genel olarak hazırlıksız yakalamıştır ve meydana geldiği toplum üzerinde sosyal, psikolojik ve ekonomik yıkıma neden olmuştur. Afetlerin meydana gelmesini tetikleyen çeşitli etmenler vardır. Bunların doğal kökenli ve insan kökenli olduğu görülmektedir. ${ }^{1}$ Oluş nedeni ne olursa olsun her iki afet türünün de ortak noktası sosyal yaşamı durdurma veya sekteye uğratacak potansiyele sahip olmasıdır. ${ }^{2}$

$\mathrm{Bu}$ durum, doğal afet eğitiminin verilmesinin ne kadar önemli olduğu konusunda bize bir göstergedir. Doğal afetler konusunda alınan eğitim kriz evresinin daha iyi biçimde yönetilmesine katkıda bulunacağı için önem arz eden bir konudur. ${ }^{3}$

Okuryazarlık kavramı düşünülen kalıpların dışında okuyan öğrenen anlamında değildir. Tam tersine bir konu üzerinde gerekli bilgiye ve donanıma sahip olan kişinin yetkinlik kazanmasıdır. ${ }^{4}$

Sadece doğal afet konusunda değil okuryazarlık diğer alanlarda da uzmanlaşmaya yönelik bir kavramdır. Ancak dünyanın bugüne kadar doğal afetlerden görmüş olduğu zararın bilançosu oldukça fazla olduğundan doğal afet okuryazarlığ özellikle araştırılan ve önemsenen bir konu halini almıştır. ${ }^{4}$

$\mathrm{Bu}$ çalışmanın amacı, Osmaniye ilinin merkez ilçesinde çalışan ilkokul/ortaokul öğretmenlerinin doğal afet okuryazarlık seviyelerini belirlemek, doğal afet okuryazarlığın alt faktörleri (davranış, duyuşsal eğilim ve bilgi) arasında çeşitli değişkenlerin etkisini ölçmektir.

\section{Kavramsal Çerçeve}

\section{Okuryazarlık}

Okuryazarlık, yazıları ve yazılarda mevcut olan sembolleri anlama, kavrama ve daha anlamlı olarak anlamlandırarak kendi özünü katarak kendini ifade etme durumudur. ${ }^{5}$

Okuryazarlık, bilgi ve becerilerinin süreç halinde okur yazarlık düzeyleri ve bu düzeylere bağlı yetenek olarak da tanımlanabileceği gibi, anlama, yorumlama, analiz etme, değerlendirebilme ve bu alanda sorunları çözüme kavuşturabilmektir. ${ }^{6}$

Çoklu (multifonksiyonel) okuryazarlık, okur-yazar ile ilgili temel bilgi ve becerilerin sağlanmasına, bu bilgilerin bireysel, sosyal, ekonomik ve kültürel alanlarda kullanılabilmesi düzeydir. $\mathrm{Bu}$ düzeydeki okuryazarlık bireyve toplumun daha ileri düzeylere gitmesine imkân sağlar. ${ }^{7}$

\section{Doğal Afet Okuryazarlığı}

Toplumların doğal afetlere yönelik bilgi, tutum ve davranışlardaki eksiklik nedeniyle doğal afetlerin olumsuz etkileri gün geçtikçe daha farklı boyutlara ulaşmaktadır. Doğal afet eğitimi, doğal afetlerin olumsuz etkilerini azaltma anlamında büyük önem arz etmektedir. $^{8}$

Doğal afet okuryazarlığ tolumun afet öncesi ve sonrasinda tutum ve davranışları olumlu etkileyen ve doğru karar vermesini sağlayan, tutum ve davranışlara sahip olmasıdır. ${ }^{8}$

Doğal afet okuryazarlığına sahip bireyin konuyla ilgili bilgi, tutum ve davranışlara sahip olduğu kabul edilmektedir. Doğal afet okuryazarlığı üç boyuta sahiptir:

- İlk boyut bilgi boyutudur. Günlük hayatımıza katkı sağlamayan bilgi pekbir anlam ifade etmemektedir.

- İkinci boyut, sahip olunan bilgilerin özümsenmesi ve tutum olarak ortaya çıkmasıdır.

- Üçüncü boyut, edinilen bilginin davranış haline dönüşmesi ve benimsenmesidir. $\mathrm{Bu}$ boyut ileri doğal afet okuryazarlığıdır. ${ }^{3}$

Sonuç olarak baktığımız da doğal afet okuryazarı, doğanın ilke ve sınırlarını bilir, 
doğal afetler konusunda sahip olduğu bilginin nasıl değerlendirileceğgi konusunda gerekli yetiye sahiptir, doğal afetler sonucunda meydana gelecek tahribatın büyüklügüünün ve ne şekilde mücadele edeceği konusunda gereken bilgiye sahiptir, sorumluluk sahibidir, gönüllü faaliyetlere katılır, sonuçları analiz eder, çevresine karşı uyarılarda bulunur. Bunun gibi pek çok özellik doğal afet okuryazarı olmanın önemini ve sayısının fazla olması doğal felaketler karşısında oluşacak sağlıklı ortama katkı sağlamak açısından önemlidir. ${ }^{3}$

\section{Doğal Afetler}

Afetler kendi içerisinde doğal kökenli ve insan kökenli afetler olmak üzere sınıflandırılmaktadır. Doğal kökenli afetleri incelediğimiz bu başlıkta tanımına baktığımızda; Antropojenik etkenlerin dışında gelişen jeolojik, klimatolojik, hidrolojik, meteorolojik ve dünya dişı olayların neticesinde, ülkelerin, toplumların ve bireylerin maddi ve manevi şekilde zarar görmesi olarak tanımlanmaktadır. ${ }^{9}$

Bununla birlikte, ekonomik açıdan bakıldığında, doğal bir felaket, ekonomik sistemin işleyişinde bozulmaya neden olan ve varlıklar, üretim faktörleri, üretim, istihdam veya tüketim üzerinde önemli olumsuz etkileri olan doğal bir olay olarak tanımlanabilir. $\mathrm{Bu}$ tür doğal olaylara örnek olarak depremler, firtınalar, kasırgalar, yoğun yağışlar, kuraklıklar, sıcak dalgalar, soğuk hava firtınası ve firtınalar ve şimşekler verilebilir. $^{10}$
Günümüzde ise bu sınıflandırma Afetlerin Epidemiyolojisi Araştırma Merkezi (CRED) tarafından daha ayrıntılı bir şekilde EM-DAT veri tabanında güncellenmiştir. ${ }^{11}$

\section{Doğal Afetlerin Sınıflandırılması}

Doğal afetlerin EM-DAT tarafindan yapılan sınıflandırmasına ek olarak ülkemizde AFAD tarafından meydana geliş sürelerine göre doğal afetlerin sınıflandırılması;

Yavaş gelişen doğal afetler arasında aşırı soğuklar, kıtlık, kuraklık yer almaktadır. Ani gelişen doğal afetler ise deprem, toprak kaymaları, çı̆̆, seller,kaya düşmeleri, su taşkınları, hortumlar, fırtınalar, volkanlar, yanginlardır. ${ }^{12}$

\section{Öğretmenler ve Okuryazarlık}

İngiltere de öğretmenler; öğrencilerin daha etkili okuryazar olmaları için eğitim öğretimde görevlendirilmektedir. Yüksek kaliteli okuryazarlık öğretimi için yüksek kaliteli öğretmenler gerekmektedir. ${ }^{13}$

Öğretmenlerin etkili bilgi ve donanımlarının, öğretmenlerin sınıf tutum ve davranışlarının ve öğretmenlerin güncel araştırmaları öğrenci okuryazarlıkları konusunda gelişmeyi etkilemiştir. ${ }^{14}$

$\mathrm{Bu}$ çalışma öğretmenlerin öğrenci ve toplum üzerinde okuryazarlık duygu ve davranışsal etkisinin araştırılması için yapılmıştır. Okuryazarlık eğitiminde öğretmenlerin etkin rol oynadığı anlaşılmıştır.

Sonuç olarak okuryazarlık kavramı en çok eğitim bilimlerini ilgilendirdiği için; bu çalışma öğretmenler üzerine uygulanmıştır.

\section{MATERYAL VE METOT}

\section{Problemin Durumu}

Afetlerin yaşanması ve verdiği zararları ele alacak olursak doğal afetler bu siralamada ön plandadır. Doğal afetler doğa olaylarındaki değişimler sonucu ortaya çıkan ve toplumu olumsuz etkileyen, toplumun başa çıkma gücünü ve müdahalesinin yetersiz olduğu durumlardir.

\section{Problem Cümlesi}

Osmaniye ilinin merkez ilçesinde çalışan ilkokul/ortaokul öğretmenlerinin davranış, duyusal eğilim ve bilgi durumları ne düzeydedir?

\section{Araştırmanın Amacı}

Araştırma, tanımlayıcı tipte bir çalışmadır. $\mathrm{Bu}$ çalışmanın amacı, Osmaniye ili merkez ilçesinde görev yapan ilkokul/ortaokul öğretmenlerinin doğal afet okuryazarlık 
seviyelerini belirlemek ve doğal afet okuryazarlığın alt faktörleri (davranış, duyuşsal eğilim ve bilgi) arasında çeşitli değişkenlerin etkisini ölçmektir.

\section{Araştırmanın Önemi}

Afetler ile mücadele konusunda toplumun bilinç düzeyinin ve okuryazarlık düzeyinin ele alınmasını ve değerlendirilmesine bu çalışmamızda önem vermekteyiz. Çünkü okuryazarlık düzeyi yüksek olan toplumun afetler ile başa çıkma ve afetin hazırlik evresinde etkin rol oynamaktadır. Topluma eğitimler ve tatbikatlar yaparak bilinçli bireyler yetiştirilmesi afetin doğuracağı zararı en aza indirecektir.

\section{Araştırmanın Kapsamı}

Çalışma kapsamında Osmaniye ili merkez ilçesinde görev yapan ilkokul/ortaokul öğretmenlerine ulaşılarak üç alt faktörden oluşan (davranış, duyuşsal eğilim ve bilgi) doğal afet okuryazarlık düzeylerini ölçen anket formu uygulanmıştır. Anket formu kapsamında cinsiyet,yaş, medeni durum, branş, anne ve baba eğitim durumu, çalışma süresi, çocuk sahibi olma durumu, doğal afet konulu ders alma durumu, afete maruz kalma durumu, birinci derece yakınlarının afette kayıp yaşama durumu, afet planında yer alma durumu, doğal afetler ile ilgili faaliyete katılma durumu, doğal afetler ile ilgili resmi kurum adi bilme durumu, acil toplanma yerini bilme durumu, okulda afet planı olma durumu, doğal afet konusunda ne kadar donanımlı olma durumu değişkenlerin doğal afet okuryazarlığın alt faktörler arasındaki ilişki değerlendirilecektir. Toplamda Osmaniye ili merkez ilçesinde görev yapan 2782ilkokul/ortaokul öğretmenlerinden 327 kişiye ulaşılmıştır.

\section{Veri Toplama Araçları ve Yöntem}

Araştırma, tanımlayıcı tipte bir çalışmadır. Araştırmanın verileri Ufuk SÖZCÜ tarafından 2019 yılında "Öğretmen Adaylarının Doğal Afet Okuryazarlık Düzeylerinin Belirlenmesi" isimli çalışmasında geliştirdiği anket ölçeği kullanılarak toplanmıştır ${ }^{3}$. Çalışmada Doğal afetler duyuşsal eğilimler ölçeği güvenirlik analizinde; duyuşsal eğilimler ölçeği alt boyutları olarak, duyarlılık 15 maddelik soruda Cronbach katsayı değeri 0,867, bilinçlilik 7 maddelik soru ile Cronbach katsayı değeri 0,761, Bireysel ve Toplumsal Hazırlık 3 maddelik soru ile Cronbach katsayı değeri 0,505 olarak belirlenmiştir. Doğalafetler davranış ölçeği güvenirlik analizinde ise davranış ölçeği alt boyutlar1; Coğrafi sorgulama 10 maddelik soru ile Cronbach katsayı değeri 0,856 kişisel koruma tedbiri 6 maddelik soru ile Cronbach katsayı değeri 0,906 ve fiziksel ve fikirsel Yaklaşım 7 soruluk madde ile Cronbach katsayı değeri 0,718 olarak belirlenmiştir. Çalışmamızda kullanılan anket dört bölümden oluşmaktadır. Birinci bölümde sosyodemografik bilgiler, ikinci bölümde doğal afet okuryazarlığı davranış ölçeği, üçüncü bölümde doğal afet okuryazarlığı duyuşsal eğilim ölçeği, dördüncü bölümde ise doğal afet okuryazarlığ İkinci bölümde yer alan doğal afet okuryazarlığı davranış ölçeğinde üç alt başlık (coğrafi sorgulama, kişisel koruma tedbiri, fiziksel ve fikirsel yaklaşım) bulunmaktadır. Üçüncü bölümde yer alan doğal afet okuryazarlığı duyuşsal eğilim ölçeğinde üç alt başlık (duyarlılık, bilinçlilik, bireysel ve toplumsal hazırlık) bulunmaktadır. Dördüncü bölümde yer alan doğal afet okuryazarlığ1 başarı testinde ise altı alt başlık (hatırlama, anlama, uygulama, çözümleme, değerlendirme, yaratma) bulunmaktadır. Verilerin analizinde tanımlayıcı istatistiksel metotların (ortalama, standart sapma vb.) yanı sıra niceliksel verilerin karşılaştırılmasında, grupların dağılımları varyans analizi ile değerlendirilmiş, normal dağılım gösteren parametrelerin gruplar aras1 karşılaştırmalarında Oneway Anova testi ve farklılığa neden olan grubun tespitinde PostHoc testlerinden Tukey HSD testi kullanılmıştır. Güvenirlik için Reliability Analysis kullanılmıştır. Anlamlılık değeri $\mathrm{p}<0,05$ düzeyinde değerlendirilmiştir.

Doğal afet okuryazarlığı davranış düzeyi puan skalasi; 2,33 ile 1 arasinda olanlar "yüksek", 3,67 ile 2,34 arasinda olanlar "orta", 5 ile 3,68 arasında olanlar "düşük" olarak yorumlanmıştır. 


\section{Araştırmanın Etik Yönü}

Araştırmanın yapılabilmesi için Gümüşhane Üniversitesi Bilimsel Araştırma ve Yayın Etiği Kurulu'ndan gerekli onay (Karar No: 32217192-605.01-E21530583) alınmıştır. Araştırmanın gerçekleştirildiği Osmaniye Valiliği İl Milli Eğitim Müdürlüğü'nden Kurum izni (01.11.2019 tarih ve 32217192-605.01-E21530583say1) alınmıştır.

\section{BULGULAR VE TARTIŞMA}

Araştırmaya dâhil edilen katılımcıların demografik bilgileri Tablo 1'ye göre değerlendirildiğinde; katılımcıların 146'sının $(\% 44,6)$ erkek olduğu görülmektedir. Katılımcilar yaşlarına göre değerlendirildiğinde ise; 92 'sinin $(\% 28,1) 18$ 30 yaş grubu, olduğu görülmektedir. Katılımcılar branşlarına göre değerlendirildiğinde ise; 84'ünün $(\% 25,7)$ matematik branşında olduğu görülmektedir. Araştırmaya katılanların medeni durumlarına göre dağılımları incelendiğinde; 211'inin $(\% 64,5)$ evli, olduğu görülmektedir. Katılımcıların çalışma sürelerine göre dağılımları değerlendirildiğinde; 173'ünün $(\% 52,9) \quad 6-10$ yıl aralığında, olduğu görülmektedir. Katılımcıların 305'i $(\% 93,3)$ doğal afet konularını içeren ders aldığını görülmektedir. Katılımcıların 241'i $(\% 73,7)$ birinci derece yakınlarının doğal afet yaşadığını belirtmiştir. Katılımcıların okullarındaki afet planında yer alma durumlarına göre değerlendirildiğinde; 308 'i $(\% 94,2)$ yer aldığını belirtmektedir. Katılımcıların 314'ü $\quad(\% 96,0) \quad$ okuldaki toplanma yerini bildiği görülmektedir.

Tablo 1. Demografik Bilgiler

\begin{tabular}{llll}
\hline Özellik & Dağılım & Sayı & $\begin{array}{l}\text { Yüzde } \\
\mathbf{( \% )}\end{array}$ \\
\hline Cinsiyet & Kadın & 146 & 44,6 \\
\cline { 2 - 4 } & Erkek & 181 & 55,4 \\
\hline Medeni durum & Evli & 211 & 64,5 \\
\cline { 2 - 4 } & Bekâr & 116 & 35,5 \\
\hline \multirow{2}{*}{ Yaş } & $18-30$ & 92 & 28,1 \\
\cline { 2 - 4 } & $31-45$ & 175 & 53,5 \\
\hline Branş & 46 ve üzeri & 60 & 18,3 \\
\cline { 2 - 4 } & Fen Bilgisi & 47 & 14,4 \\
\cline { 2 - 4 } & Sinıf Öğrt. & 62 & 19,0 \\
\cline { 2 - 4 } & Sosyal & 56 & 17,1 \\
& Bilgiler & & \\
\cline { 2 - 4 } & Matematik & 84 & 25,7 \\
\cline { 2 - 4 } & Diğer & 78 & 23,9 \\
\hline Çalışma süresi & $0-5$ yıl & 44 & 13,5 \\
\cline { 2 - 4 } & 6-10 yıl & 173 & 52,9 \\
\cline { 2 - 4 } & & 110 & 33,6 \\
\hline
\end{tabular}

\begin{tabular}{|c|c|c|c|}
\hline \multicolumn{4}{|l|}{ Tablo 1 (Devamı). } \\
\hline \multirow{2}{*}{$\begin{array}{l}\text { Doğal afetler ile } \\
\text { ilgili ders alma } \\
\text { durumu }\end{array}$} & Evet & 305 & 93,3 \\
\hline & Hayır & 22 & 6,7 \\
\hline \multirow{2}{*}{$\begin{array}{l}\text { Yakınınız Hiç } \\
\text { Doğal Afet Yaşadı } \\
\text { mı? }\end{array}$} & Evet & 241 & 73,7 \\
\hline & Hayır & 86 & 26,3 \\
\hline \multirow{2}{*}{$\begin{array}{l}\text { Afet planında yer } \\
\text { alıyor musunuz? }\end{array}$} & Evet & 308 & 94,2 \\
\hline & Hayır & 19 & 5,8 \\
\hline \multirow{3}{*}{$\begin{array}{l}\text { Okulunuzda } \\
\text { planı var mı? }\end{array}$} & Evet & 313 & 95,7 \\
\hline & Hayır & 7 & 2,1 \\
\hline & Bilmiyorum & 7 & 2,1 \\
\hline \multirow{2}{*}{$\begin{array}{l}\text { Acil toplanma } \\
\text { yerini biliyor } \\
\text { musunuz? }\end{array}$} & Evet & 314 & 96,0 \\
\hline & Hayır & 13 & 4,0 \\
\hline
\end{tabular}

Çalışma, 72 soru üzerinden güvenirlik analizine tabi tutulması sonucu Cronbach's Alfa değeri 0,714 olduğu görülmüştür. Ölçek uyarlama ve geliștirme çalıșmalarında Cronbach's alfa değerinin 0,700 ve üzeri olması gerektiği genel olarak kabul görmektedir. ${ }^{15}$ Sonuç olarak çalışmamız güvenilirdir.

Tablo 2'ye göre araştırmaya dâhil edilen katılımcıların doğal afet okuryazarlığ davranış düzeyi puan ortalamaları 1,67 $\pm 0,294$ olduğu görülmektedir. Belirleneskalaya göre 1,67'lik puan ortalaması yüksek seviye olarak kabul edilmiştir. Araştırmaya dâhil edilen katılımcıların doğal afet okuryazarlığı duyuşsal eğilim düzeyi puan ortalamaları $1,85 \pm 0,255$ olarak bulunmuştur. Belirlenen skalaya göre $1,85^{\prime}$ lik puan ortalaması yüksek seviye olarak kabul edilmiştir. Araştırmaya dâhil edilen katılımcıların doğal afet okuryazarlığı bilgi düzeyi puan ortalamaları $87,62 \pm 9,022$ olarak bulunmuștur. 
Tablo 2. Doğal Afet Okuryazarlığı Davranış, Duyuşsal Eğilim ve Bilgi Düzeyi Puan Ortalamaları

\begin{tabular}{lcc} 
& N & Ort. \pm Ss. \\
\hline $\begin{array}{l}\text { Doğal Afet } \\
\text { Okuryazarlığı } \\
\text { Davranış Düzeyi } \\
\text { Puan Ortalamaları }\end{array}$ & 327 & $1,67 \pm 0,294$ \\
\hline $\begin{array}{l}\text { Doğal Afet } \\
\text { Okuryazarlığı } \\
\text { Duyuşsal Eğilim } \\
\text { Düzeyi Puan } \\
\text { Ortalamaları }\end{array}$ & 327 & $1,85 \pm 0,255$ \\
\hline $\begin{array}{l}\text { Doğal Afet } \\
\text { Okuryazarlığı Bilgi } \\
\text { Düzeyi Puan } \\
\text { Ortalamaları }\end{array}$ & & \\
\hline
\end{tabular}

Belirtilen skalaya göre katılımcıların doğal afet okuryazarlığı coğrafi sorgulama düzeyleri, doğal afet okuryazarlığı kişisel koruma tedbiri düzeyleri ve doğal afet okuryazarlığı fiziksel ve fikirsel yaklaşım düzeyleri yüksek seviyede olduğu görülmüştür.

Tablo 3'e göre araştırmaya dâhil edilen katılımciların doğal afet okuryazarlığ duyuşsal eğilim ölçeğinin 3 alt başlıklarına göre puan ortalamaları değerlendirildiğinde, doğal afet okuryazarlığ 1 duyarlılık düzeyi puan ortalamaları $1,59 \pm 0,260$, doğal afet okuryazarlıği bilinçlilik düzeyi puan ortalamaları 1,74 $\pm 0,537$, doğal afet okuryazarlığ 1 bireysel ve toplumsal hazırlık düzeyi puan ortalamaları $3,43 \pm 0,421$ olarak bulunmuştur. Belirlenen skalaya göre katılımcıların doğal afet okuryazarlığ duyarlılık düzeyleri ve doğal afet okuryazarlığg bilinçlilik düzeyleri yüksek seviyede olduğu görülmektedir. Doğal afet okuryazarlığ düzeyleri ise orta seviyede olduğu görülmektedir.
Tablo 3. Doğal Afet Okuryazarlığı Davranış Duyuşsal Eğilim Düzeyi Puan Ortalamalarının Alt Başlıklara Göre Dağılımı

\begin{tabular}{cccc}
\hline & $\begin{array}{c}\text { Duyarlılık } \\
\text { Düzeyi } \\
\text { Puan Ort. }\end{array}$ & $\begin{array}{c}\text { Bilinçlilik } \\
\text { Düzeyi } \\
\text { Puan Ort. }\end{array}$ & $\begin{array}{c}\text { Bireysel } \\
\text { ve } \\
\text { Toplumsal } \\
\text { Hazırlık } \\
\text { Düzeyi } \\
\text { Puan Ort. }\end{array}$ \\
\hline Ort.Ss. & $1,59 \pm 0,260$ & $1,74 \pm 0,537$ & $3,43 \pm 0,421$ \\
\hline & $\begin{array}{c}\text { Corgugrafi } \\
\text { Düzeyi } \\
\text { Puan Ort }\end{array}$ & $\begin{array}{c}\text { Kişisel } \\
\text { Koruma } \\
\text { Tedbiri } \\
\text { Düzeyi } \\
\text { Puan Ort. }\end{array}$ & $\begin{array}{c}\text { Fiziksel ve } \\
\text { Fikirsel } \\
\text { Yaklaşım } \\
\text { Düzeyi } \\
\text { Puan Ort. }\end{array}$ \\
\hline Ort.Ss. & $1,64 \pm 0,346$ & $1,76 \pm 0,538$ & $1,65 \pm 0,450$ \\
\hline
\end{tabular}

Tablo 4'e göre katılımciların doğal afet okuryazarlığ 1 duyarlılık düzeyi puan ortalamaları, branş durumlarına göre değerlendirildiğinde, istatistiksel olarak anlamlı farklılık bulunduğu görülmektedir $(p<0,05)$. Diğer grubunda yer alan ögretmenlerin (beden eğitimi, rehberlik, idareci vb.) doğal afet okuryazarlığı duyarlılık düzeyi puan ortalamaları $1,64 \pm 0,270$ olduğu görülmektedir. $\mathrm{Bu}$ doğal afet okuryazarlığ duyarlılık düzeyi puan ortalaması belirlenen skalaya göre yüksek düzey olduğu görülmektedir. Diğer grubunda yer alan öğretmenlerin (beden eğitimi, rehberlik, idareci vb.) doğal afet okuryazarlığı duyarlılık düzeyi puan ortalaması diğer öğretmenlere (fen bilgisi, sosyal bilgiler, matematik ve sinıf öğretmenliği) göre daha yüksek olduğu görülmektedir. Katılımcıların doğal afet okuryazarlığg bilgi düzeyi puan ortalamaları, branşlarına göre değerlendirildiğinde, istatistiksel olarak anlaml farklılık bulunmuştur $(p<0,05)$. Sosyal bilgiler öğretmenlerin doğal afet okuryazarlığı bilgi düzeyi puan ortalamalar $94,49 \pm 0,270$ olduğu görülmektedir. Sosyal bilgiler öğretmenlerin doğal afet okuryazarlığı bilgi düzeyi puan ortalaması diğer öğretmenlere göre (fen bilgisi, matematik, rehberlik, beden eğitimi, sınıf öğretmenliği vb.) göre daha yüksek olduğu görülmektedir. 
Tablo 4. Branşlar ile Likert Ortalamaları (OneWay ANOVA)

\begin{tabular}{|c|c|c|c|c|c|c|}
\hline & Branş & $\mathbf{N}$ & Ort. & SS. & Std Hata & $\mathbf{p}$ \\
\hline \multirow[t]{5}{*}{ Duyarlılık Düzeyi Puan Ort. } & Fen Bilgisi & 47 & 1,62 & 290 & ,042 & \multirow[t]{5}{*}{, 018} \\
\hline & Sınıf Öğr. & 62 & 1,57 & 234 & 029 & \\
\hline & Sosyal Bilgiler & 56 & 1,50 & 261 & ,034 & \\
\hline & Matematik & 84 & 1,61 & ,238 &, 026 & \\
\hline & Diğer & 78 & 1,64 & 270 &, 030 & \\
\hline \multirow[t]{5}{*}{ Bilgi Düzeyi Puan Ort. } & Fen Bilgisi & 47 & 86,65 & 9,825 & 1,433 & \multirow[t]{5}{*}{,000 } \\
\hline & Sınıf Öğr. & 62 & 85,95 & 8,419 & 1,069 & \\
\hline & Sosyal Bilgiler & 56 & 94,49 & 7,679 & 1,026 & \\
\hline & Matematik & 84 & 86,17 & 9,503 & 1,36 & \\
\hline & Diğer & 78 & 86,18 & 7,060 & ,799 & \\
\hline
\end{tabular}

Tablo 5'de MeanRank sıralama ölçütüne göre; katılımcıların doğal afet okuryazarlığ 1 kişisel koruma tedbiri düzeyi puan ortalamaları, afet planında yer alma durumlarına göre değerlendirildiğinde, istatistiksel olarak anlamlı farklılık bulunmuştur $(p<0,05)$. Afet planında yer almayan katılımcıların doğal afet okuryazarlığ kişisel koruma tedbiri düzeyi puan ortalamaları afet planında yer alan katılımcılara göre daha yüksek olduğu görülmektedir. Katılımcıların doğal afet okuryazarlığ 1 bireysel ve toplumsal hazırlık düzeyi puan ortalamaları, afet planında yer alma durumlarına göre değerlendirildiğinde, istatistiksel olarak anlaml farklılık bulunmuştur $(p<0,05)$. Afet planında yer alan katılımcıların doğal afet okuryazarlığı bireysel ve toplumsal hazırlık düzeyi puan ortalamaları afet planında yer almayan katılımcilara göre daha yüksek olduğu görülmektedir.

Tablo 5. Afet Planında Yer Alma Durumu (Mann-Whitney-U)

\begin{tabular}{|c|c|c|c|c|c|}
\hline & Afet Planında Yer Alma Durumu & $\mathrm{N}$ & MeanRank & $\mathrm{U}$ & $\mathrm{p}$ \\
\hline Tedbiri Düzeyi & Evet & 308 & 160,38 & \multirow[t]{2}{*}{1812,5} & \multirow[t]{2}{*}{, 005} \\
\hline Puan Ortalaması & Hayır & 19 & 222,61 & & \\
\hline \multirow{2}{*}{$\begin{array}{l}\text { Bireysel ve Toplumsal Hazırlık } \\
\text { Düzeyi Puan Ortalaması }\end{array}$} & Evet & 308 & 166,45 & \multirow[t]{2}{*}{2172,0} & \multirow[t]{2}{*}{,049 } \\
\hline & Hayır & 19 & 124,32 & & \\
\hline
\end{tabular}

Karakuş ve Önger (2017) Kütahya ili Simav ilçesindeki bir ortaokulun 8. Sinıf öğrencilerine doğal afet ve afet eğitimi kavramını anlama düzeylerini ölçmek için nitel bir çalışma yapıldığ 1 görülmektedir. ${ }^{16}$ Çalışma sonucunda öğrencilerin afet denince akıllarına ilk olarak deprem geldiğini belirlenmektedir. Bu konuda çevresel şartlar ve öğrencilerin yaşadığı yörenin afetselliğinin öneminin vurgulandiğı görülmektedir. Ayrıca doğal afet ve afet eğitiminde bilgi eksikliğine değinerek afet eğitiminin gerekliliğini önerilmektedir. Çalışmamızda da benzer bir şekilde katılımcılara "yaşadığım yörede oluşabilecek doğal afetlerin farkındayım" sorusu sorulduğunda 160 kişi $(\% 48,9)$ tamamen katılıyorum cevabını verildiği görülmektedir. Ayrıca katılımcılara "doğal afet eğitiminin vatandaşlarımızın bilinç düzeyini artıracağ 1 fikrini savunurum" sorusu sorulduğunda ise 184 kişi $(\% 56,3)$ tamamen katılıyorum cevabının verildiği görülmektedir. Çalışma grubumuzu oluşturan öğretmenler de afetlerde çevresel şartların ve afet eğitiminin önemliliğini vurgulanmaktadır.

Chung ve Yen (2016) Taiwan'da okul yöneticileri ve öğretmenlere afet önleme okuryazarlığı üzerine yaptığı çalışmada afet önleme okuryazarlığını üç başlık (bilgi, tutum ve beceri) altında incelendiği görülmektedir. ${ }^{17}$ Çalışma sonucuna göre katılımcıların afet önleme becerileri yüksek, afet önleme bilgileri ise düşük olduğunu görülmektedir. Çalışmamızda ise öğretmen ve okul yöneticilerine doğal afet okuryazarlığ1 konusunda anket uygulanmıştır. Çalışmamızda doğal afet okuryazarlığı; 
davranış, duyuşsal eğilim ve bilgi olmak üzere üç başlıkta toplanmaktadır. Çalışma sonucumuza göre, araştırmaya dâhil edilen katılımcıların doğal afet okuryazarlığ davranış düzeyi puan ortalamaları 1,67 $\pm 0,294$ olarak bulunmuştur. Belirlenen skalaya göre $1,67^{\prime}$ lik puan ortalaması yüksek seviye olduğu görülmektedir.

Taş (2003), ortaöğretim kurumlarında doğal afet konularının öğretimini değerlendirmeye yönelik bir çalışma yaptığ 1 görülmektedir. ${ }^{18}$ Farklı tezlerden yararlanarak ve uzman görüşü alarak oluşturduğu ölçme aracını verilerin toplamak için kullanılmaktadır. Araștırmanın örneklemini Ankara Mamak ilçesinde öğrenim gören 194 lise öğrencisi ve 33 coğrafya öğretmeni oluşturduğu görülmektedir. Taş'ın çalışmasında ortaya çıkan veriler neticesinde öğretmen ve öğrencilerin daha önce doğal afet yaşama durumlarının doğal afetler konusuna ilgiyi artırdığını ve bu yaşanmışlıklardan dersin anlatımında etkili olduğu sonucuna varıldığı görülmektedir. Araştırmamızın örneklemini oluşturan ilkokul ve ortaokul öğretmenlerinde ise doğal afet yaşama durumlarının davranışlarına etkisine bakıldığında ise Taş'ın çalışmasına göre farklı sonuçlar elde edilmektedir. Toplanan veriler neticesinde doğal afet yaşamayan ilk ve ortaokul öğretmenlerinin doğal afetler konusunda okuryazarlık davranış düzeyinin yaşayanlara göre daha yüksek olduğu görülmektedir. Her iki çalışma arasında bu noktada karşıt sonuçlar ortaya çıkmaktadır. Ayrıca okuryazarlık kavramı bilginin tutum ve davranışlarla ortaklaşa bir hareketi olduğu için kullanmış olduğumuz kavram davranış durumuyla doğrudan ilişkilidir.

Uzunyol (2012) iki bölümden oluşan bir ölçek kullanarak 8. Sınıf öğrencilerinin doğal afetler konusunda bilgi düzeyini belirlemeye yönelik bir çalışma yaptığı görülmektedir. ${ }^{19}$ Araştırmada kullanılan ölçeğin ilk bölümünde öğrencilerin kişisel özellikleriyle ilgili sorular bulunurken ikinci bölümünde doğal afet bilgi düzeyini belirlemeye yönelik sorular vardır. Araştırmanın örneklemini her ilden tesadüfü örnekleme yoluyla seçilen 384 sekizinci sınıf öğrencisi oluşturmaktadır. Sonuç olarak öğrencilerin 3\4'ünün doğal afetler konusunda bilgi sahibi oldukları görülmektedir. Öğretmenlerle gerçekleştirdiğimiz çalışmanın sonucunda ise doğal afet okuryazarlığını belirlemeye yönelik sorduğumuz doğal afetlerle ilgili bilgi sorularına verdikleri cevaplara göre öğretmenlerin bilgi düzeyi çok yüksek seviyede çıktığı görülmektedir. Her iki çalışmanın sonuçları bu noktada paralel sonuçlar göstermektedir. Sözcü 2019 yılında fen bilgisi, sınıf öğretmenliği ve sosyal bilgiler öğretmenliği 4. sınıf öğrencileriyle doğal afet okuryazarlığı düzeyini belirlemeye yönelik araştırma yaptığı görülmektedir. Araştırma 8 farklı üniversitede öğrenim gören 1218 öğretmen adayıyla yapıldığı görülmektedir. Veri toplama aracı olarak ise anket kullanıldığı görülmektedir. Anket kişisel bilgiler, davranış, duyuşsal ve bilgi boyutlarını içermektedir. Sözcü, branşın bilgi testi üzerine anlamlı farklılığını incelediği ve sınıf öğretmenliği öğrencilerinin diğer iki branşa göre anlamlı düzeyde yüksek olduğu sonucuna ulaştığ 1 görülmektedir. Üzerinde çalışmış olduğumuz araştırmanın sonucunda ise sosyal bilgiler öğretmenlerin doğal afet okuryazarlığ 1 bilgi düzeyi puan ortalamasının diğer öğretmenlere göre (fen bilgisi, matematik, rehberlik, beden eğitimi, sınıf öğretmenliği vb.) göre daha yüksek olduğu görülmektedir. $\mathrm{Bu}$ noktada Sözcü'nün çalışmasına göre farklı sonuçlar elde edildiği görülmektedir. 


\section{SONUÇ VE ÖNERILER}

Araştırma sonuçlarına göre öğretmenlerin çoğunluğu doğal afetlerle ilgi faaliyetlere katıldığını ve katılmak istediğini belirtmişlerdir. $\mathrm{Bu}$ sonuç bağlamında öğretmenlere doğal afetlerle ilgili seminer, konferans, eğitim ve tatbikat gibi faaliyetler düzenlenmelidir. Araştırma sonuçlarına göre yangın tatbikatına katılmak isteyen öğretmenlerin doğal afet okuryazarlığı davranış düzeyi puan ortalamaları yangın tatbikatına katılmak istemeyen öğretmenlere göre daha yüksek olduğu görülmüştür. $\mathrm{Bu}$ sonuç bağlamında öğretmenlerin ders, sınav, yazılı gibi teorik bilgilerden çok uygulamaya yönelik faaliyetlerin etkili olacağı düşünüldüğü ön görülmektedir. $\mathrm{Bu}$ yüzden okullarda yapılan yangın tatbikatlarında uygulamalar arttırılmalı, yaratıcı ve gerçekçi senaryolarla tatbikatlar güçlendirilmelidir.

Çalışmamızda yapmış olduğumuz araştırmalar gösteriyor ki, doğal afet konularını içeren ders alan katılımcıların doğal afet okuryazarlığ 1 coğrafi sorgulama düzeyi puan ortalamaları doğal afet konularını içeren ders almayan katılımcılara göre daha yüksektir. Bu bağlamda doğal afet konularını içeren dersler her alanda arttırılmalı, eğitim müfredatına seçmeli dersler arasına eklenmelidir. Çalışma sonucumuza göre, afet planında yer alan katılımcıların doğal afet okuryazarlığı bireysel ve toplumsal hazırlık düzeyi puan ortalamaları afet planında yer almayan katılımcılara göre daha yüksek olduğu görülmüştür. $\mathrm{Bu}$ bağlamda tüm öğretmenler ve okul yöneticiler okul afet planına dahil edilmeli, okul afet planı daha da genişletilerek tüm çalışan ve personelleri kapsamalıdır. Doğal afet okuryazarlığı ile ilgili literatürde çok fazla Türkçe yayın olmaması ve konunun önemine değinmek için bu çalışmaya başlanmıştır. Literatürdeki eksiklikleri gidermek ve literatüre katk1 sağlamak amacıyla yapılan çalışmada doğal afet okuryazarlığı ile ilgili konularda çalışma yapmak isteyenler için bir fikir oluşturacaktır.

\section{KAYNAKLAR}

1. Keller Edward, A. and Devecchio Duane, E. (2012), Natural Hazards, Third Edition, Pearson Prentice Hall, New Jersey.

2. Alcántara-Ayala, I. (2002), “Geomorphology, Natural Hazards, Vulnerability and Prevention of Natural Disasters in Developing Countries". Geomorphology, 47 (2-4), 107 124.

3. Sözcü, U. (2019). Öğretmen Adaylarının Doğal Afet Okuryazarlık Düzeylerinin Belirlenmesi, Doktora Tezi, Kastamonu Üniversitesi, Sosyal Bilimler Enstitüsü, Kastamonu.

4. Afet ve Acil Durum Başkanlığı. (2014). "2014-2023 Teknolojik Afetler Yol Haritası Belgesi". Https://Www.Afad.Gov.Tr/Kurumlar/Afad.Gov.Tr/3906/ Xfiles/Teknolojik-Afetler-Son.Pdf. (Erişim tarihi 01.04.2021).

5. Așıcı, M. (2009). "Kișisel ve Sosyal Bir Değer Olarak Okuryazarlık”. Değerler Eğitimi Dergisi, 7 (17), 9-26.

6. Ünsal, H. (2015), "The Information Literacy Level of Vocational School and Technical School Students". Journal of Theoretical Educational Science, 8 (3), 421436.

7. Güneş, F. (1994). “Okur-Yazarlık Kavramı ve Düzeyleri”, Ankara Üniversitesi Eğitim Bilimleri Fakültesi Dergisi, 27 (2), .499-507.

8. Sözcü, U. ve Aydınözü, D. (2019), “ExaminingThe Natural Disaster Literacy Levels of Pre-Service Teachers According To Some Variables". International Journal of Geography and Geography Education (Igge), 40, 79-91.
9. Yavas, H. (2005), "Türkiye'de Doğal Afetlerin Merkez Yerel İlişkiler Açısından Yönetim Sorunları”. Dokuz Eylül Üniversitesi, Sosyal Bilimler Enstitüsü Dergisi, 7 (3), 280301.

10. Hallegatte, S. and Przyluski, V. (2010). "The Economics of Natural Disasters: Concepts and Methods". The World Bank

11. Em-Dat Website. [Online]. (2009). Available: Https://Www.Emdat.Be/About. (Erişim tarihi 01.04.2021).

12. T.C İçişleri Bakanlığı AFAD ve Acil Durum Yönetim Başkanlığ 1 (2021). https://www.afad.gov.tr/. (Erişim tarihi 01.04.2021).

13. Medwell, J, Wray, D, Poulson, L. and Fox, R. (1998). Effective Teachers of Literacy.

14. Wray, D, Medwell, J, Fox, R. and Poulson, L. (2000). The Teaching Practices of Effective Teachers of Literacy. Educational Review, 52 (1), 75-84.

15. Seçer, İ. (2015). SPSS ve Lisrel İle Pratik Veri Analizi. 2. Baskı, Ankara: Anı Yayıncılık.

16. Karakuș U. ve Önger, S. (2017), "8. Sınıf Öğrencilerinin Doğal Afet ve Afet Eğitimi Kavramını Anlama Düzeyleri”. Journal of History Culture and Art Research, 6 (6), 482491

17. Chung Sung, C. and Yen Cherng, J. (2016), "Disaster Prevention Literacy among School Administrators and Teachers: A Study on the Plan for Disaster Prevention and Campus Network Deployment and Experiment in Taiwan". Journal of Life Sciences, 10, 203-214. 
18. Tas, G. (2003), Türkiye'de Ortaöğretim Kurumlarında Doğal Afetler (Deprem, Kütle Hareketleri, Volkan, Don Olayı) Konularının Öğretiminin Değerlendirilmesi (Yüksek Lisans Tezi), Gazi Üniversitesi, Sosyal Bilimler Enstitüsü, Ankara.
19. Uzunyol, B. (2013), 8. Sınıf Öğrencilerinin Doğal Afetler Hakkındaki Bilgi Düzeylerinin Çeşitli Değişkenlere Göre İncelenmesi. (Yüksek Lisans Tezi), Niğde Üniversitesi Eğitim Bilimleri Enstitüsü, Niğde. 